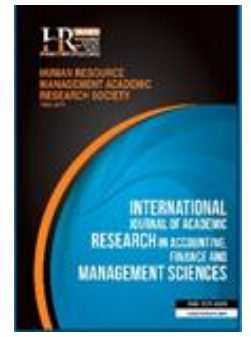

International Journal of Academic Research in Accounting, Finance and Management Sciences

Vol. 9, No.1, January 2019, pp. 170-178

E-ISSN: 2225-8329, P-ISSN: 2308-0337

(C) 2018 HRMARS

www.hrmars.com

To cite this article: Nwamgbebu O.P., Oketa C.E., Agba C.C., Nwambe, C.O. (2019). Effect of Value for Money Auditing on Cost of Governance in Nigeria: Evidence from Local Government Councils in Ebonyi State, Nigeria, International Journal of Academic Research in Accounting, Finance and Management Sciences 9 (1): 170-178.

\title{
Effect of Value for Money Auditing on Cost of Governance in Nigeria: Evidence from Local Government Councils in Ebonyi State, Nigeria
}

\author{
Nwamgbebu Obinna P. ${ }^{1}$, Oketa Chiamaka E. ${ }^{2}$, \\ Agba Chukwuka C. ${ }^{1}$, Nwambe, Cynthia $0 .^{3}$ \\ ${ }^{1}$ Department of Accountancy, Ebonyi State University, P.M.B 053, Abakaliki, \\ E-mail: obinnamgbabu@yahoo.com (Corresponding Author) \\ ${ }^{2}$ Department of Accountancy, Alex Ekwueme Federal University, Ndufu-Aliki Ikwo, Ebonyi State, Nigeria \\ ${ }^{3}$ Department of Petroleum Marketing and Business Studies, Federal Polytechnic of Oil and Gas, Bonny Island, River \\ State, Nigeria

\begin{abstract}
The study examined the effect of value for money auditing on cost of governance in local government councils in Nigeria: The specific objectives were to determine how the effects of economy principle in procurement, effect of efficiency principle in utilization of resources and effect of effectiveness principle in budget implementation have affected cost of governance in local government councils in Nigeria. The researcher adopted cross-sectional survey design which made use of primary data obtained through the use of structured questionnaires. The questionnaires were administered to 167 senior staff in account and internal audit departments, but only 108 were returned and valid for the analysis of the study. Multiple regression method anchored on ordinary least square was employed in testing the hypotheses. The result of the analysis revealed that economy principle in procurement and effectiveness principle in budget implementation have significant effect on cost of governance, while efficiency principle in utilization of resources has no significant effect on cost of governance in local government councils in Nigeria. The implication of these findings is that a good number of local government administrators in Nigeria played their role in adhering to value for money auditing principles. The study therefore concluded that adherence to the principles of value for money auditing by local government administrators in Nigeria will reduce high cost of governance. The study recommended that the office of auditor general for local government should on regular basis review audit techniques to ascertain whether their intended purposes are being achieved economically, efficiently and effectively.
\end{abstract}

Key words Cost of governance, economy, efficiency, effectiveness, value for money

Received: 30 May $2019 \quad$ (c) The Authors 2019

Revised: 15 Jun 2019 Published by Human Resource Management Academic Research Society (www.hrmars.com)

Accepted: 27 Jun 2019 This article is published under the Creative Commons Attribution (CC BY 4.0) license. Anyone may reproduce, distribute, translate and create derivative works of this article (for both commercial and non-commercial purposes), subject to full attribution to the original publication and authors. The full terms of this license may be seen at: http://creativecommons.org/licences/by/4.0/legalcode

\section{Introduction}

Prudent management of national resources is a key to rapid socio-economic development of any society. Ironically, this important virtue has eluded the Nigerian state since her independence due largely to bad leadership. As aptly captured by Achebe (1984) the root cause of the nation's predicament lay squarely at the foot of bad leadership which arises from lack of capacity to rise to their responsibility in the management of the nation's resources and affairs at all levels. It is an open secret that despite the available vast resources in Nigeria our leaders have failed to properly harness, manage and utilize the abundant 
resources for the overall development of the country. The overall implication is that Nigeria is still being categorized among the underdeveloped nations of the world (Okey and Eduno, 2014).

The most frustrating dimension of this bad leadership is the increasing manifestation of the ugly incident of wasteful spending occasioned by high cost of governance in Nigeria. To be precise, the cost of running administrative and political offices in Nigeria is on the high side and requires serious and immediate attention by well-meaning Nigerians. This explains why the development has over the years attracted several comments from scholars and other relevant stakeholders in the Nigerian project (Okeke and Eme, 2015; Akande, 2010) who expressed their deep concern about the danger of this ugly incident. Undoubtedly, the high cost of governance in Nigeria has serious implications on the country's development as it has led to: ...stark poverty of many in the midst of the provocative opulence of the few, the collapse of the healthcare system, education has become unattainable as the sky, politico-economic infrastructure resulting to the pauperization and near elimination of Nigerian middle class, pollution of values and culture as shown in massive corruption and indecency, high level of indiscipline, moral decadence, the resurgence of dangerous dimension of ethnicity, insecurity of lives and property as well as political violence (Adamu, 2008).

Unfortunately, this challenge has persisted as current political office holders in Nigeria still parade thousands of multiple aides with overlapping mandates. The unfortunate development is gradually grinding the country financially to a halt, as huge resources that could be used for socio-economic development are spent on avoidable ventures. In Ebonyi state for instance, the government has increased cost of governance through the duplication of offices at the local government level as shown in the appointment of supervisory councilors, liaison officers, management committee members, local government advisory committee members, coordinators and ward councilors. All these appointees are on monthly salaries and allowances between N150,000 - N250,000 with their negative impacts on the meager resources available to local government. This development has led to wasteful and avoidable expenditures with little or nothing left to carry out the real functions of government.

In a bid to remedy this challenge, the government had in the past adopted the use of statutory audit which focused primarily on assessing organizational performance in terms of conformity or compliance to accounting rules and regulations. However, it was later discovered that the traditional audit (statutory audit) is grossly inadequate to provide the needed information on how public resources are managed by those entrusted with the resources (Kalubanga and Kakwezi, 2013). Consequently, there was need for new approaches to public sector auditing that take into account the real value of money spent by public office holders. This onus therefore lied on the auditors to introduce an alternative method to the traditional concerns of statutory auditing which hitherto characterized the public sector expenditure management in Nigeria (Kandasamy, 2003). Subsequently, state auditors responded to the challenge by introducing value for money auditing.

Value for money auditing therefore, focuses on the systematic evaluation of the methodologies employed in the execution of programmes, projects and activities with the objectives of confirming whether the stated objectives of the programmes, projects and activities were actual achieved and at what cost. It is about achieving the right balance between economy, efficiency and effectiveness in the management of public resources. This method of audit has evolved over time and has been found to be the best approach to confirming whether managers of public resources are applying best practices in the use and management of resources. Value for money auditing has been found to be particularly useful in public sector where measurements of results achieved by public sector organizations are not based on profit. Raymond (1995) agrees with the above position when he asserted that value for money auditing is a formal tool for evaluating government performance which helps to improve accountability and transparency by providing information on the performance of government which the public may not have accessed. Many years after the introduction of this policy, the volume of empirical studies on value for money auditing in Nigeria is surprisingly small especially if compared with studies in other topics such as performance management and evaluation (Cited in Raudla et al., 2015). In line with the above observation, this study is set to evaluate the effect of value for money auditing on cost of governance in Nigeria, evidence from Local Government Councils in Ebonyi State. 


\section{Literature review}

The concept of value for money (VFM) in public sector organizations refers to the principle that public funds should be put to the best possible use and that those who conduct public businesses should be accountable economically, efficiently and effectively in the management of resources entrusted to them (office of the auditor general (OAG), Canada, 2010). In sum the scope of VFM audit include the examination of economy, efficiency, effectiveness and environmental effect on government activities. Therefore, a detailed explanation of the 3E's of value for money audit (economy, efficiency and effectiveness) is pertinent to the full understanding of VFM audit. This is shown by the diagram below.

\subsection{Conceptual Framework}

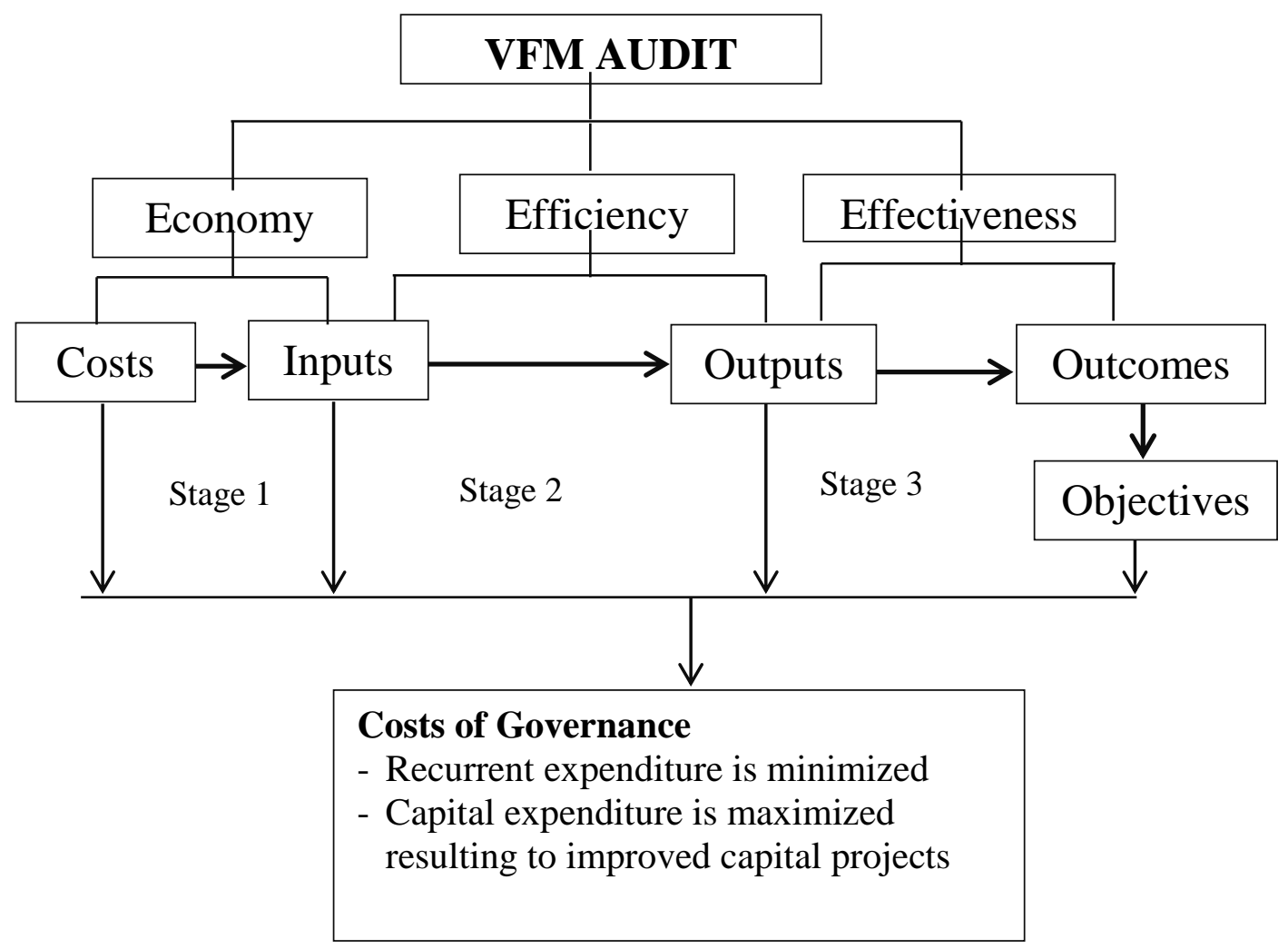

The above diagram shows that VFM audit is decomposed into economy efficiency and effectiveness. It also shows the relationship amongst these elements. For instance, the first stage involves acquisition of input resources at a very minimal cost while quality is still maintained (economy). The second stage involves effective transformation of the input resources acquired in stage one into output (efficiency). The third stage deals with comparing the output obtained in the second stage with the intended output to ascertain the extent the desired objective has been achieved (effectiveness). It is important to note that none of these stages can work independent of the other. Therefore, the three stages must be put together to achieve a target; this is called VFM audit.

Economy: This is one of the elements of value for money audit which shows the relationship between cost and input resources. Economy which can otherwise be called economy principle in procurement deals with the acquisition of inputs at the smallest price provided that the required quality is obtained. It also involves using smallest expenditure of resources to achieve a set of goal. It finds out the answer of whether physical, financial, human resources and information inputs acquired are at the right cost, right place. It also assesses whether resources were acquired at the lowest cost while maintaining quality; the lowest price is not the best if the quality is different (Mahbuba, 2012).

Efficiency: The researcher referred efficiency as efficiency principle in utilization of resources. This is the second principle or element of value for money auditing that shows the relationship between input resources and output resources (a measure of productivity). It is the efficient use of goods and services bought by an entity to achieve the desired outputs. Technical, it is concerned with output divided by inputs. 
It deals with the relationship between inputs and outputs through optimum utilization of resources. Efficiency is maximizing inputs to obtain a given outputs without sacrificing quality.

Effectiveness: This third element of value for money audit can also be called effectiveness principle in budget implementation. This principle compares organization's actual outputs with the budgetary intended objective in order to determine the extent at which such targets have been achieved. Therefore, it shows the relationship between actual output and budgetary expected output. Effectiveness is qualitative and quantitative measures of increase or decrease in outcomes that shows whether a programme is effective in delivering its intended objectives or not. Technically, it is calculated as actual output divided by expected output. It measures whether predetermined objectives are achieved or not.

Mahbuba (2010), it was stated that the process of performance (VFM) audit is made up of economy, efficiency and program (effectiveness) audits. Economy and efficiency audits determine whether the entity is following sound procurement practice, acquiring appropriate type of resources; properly protecting and maintaining resources; avoiding duplication of efforts by employees; avoiding idleness and overstaffing; using efficient operating procedure; using optimum amount of resources and has an adequate management control system. Program (effectiveness) audit on the other hand, may assess whether the objectiveness of propgram is achieved; identify factors inhibiting satisfactory performance; identify ways of making program work better and determine whether management has reported measures of program effectiveness that are valid and reliable (Megbeluba, 2010).

In conducting VFM audit, some important questions should be asked: Are there alternative course of action that can minimize cost? Are there adequate safeguard for assets?. Are the results achieved in alliance with the overall objective? Are the output achieved up to the set targets? Can result be improved without incurring additional cost? Are expenditure incurred justified and commensurate with the result processed? Are there unnecessary duplication of efforts, process or procedures? The right interrelationship among these elements is that all of them must be in place before the assessment of value for money can be said to be complete (ICAN, 2006). Right thing must be done, using the right method and at minimum cost.

The term value for money is derived from the optimal balance of benefits and cost on the basis of total cost of ownership. As such, value for money does not necessarily mean that a tender must be awarded to the lowest tenderer (Civil Service College, 2010). It is a term generally uses to describe an explicit commitment to ensuring that the best results possible are obtained from the money spent. In the UK government, use of this term reflects a concern for more transparency and accountability in spending public funds; and for obtaining maximum benefit from the resources available (Barnett, Christie, Duff and Hext, 2010). Value for money refers to the judicious, economic and efficient use of public resources at a reasonable cost. In the public sector, it involves consideration of the contribution to be made to advancing government policies and priorities while achieving the best return and performance for the money spent (Bauld and McGuiness, 2006). This implies that public entities can choose to award a contract based on other criteria other than the lowest price; one of the factors considered is the whole life cycle cost (Raymond, 2008).

Cost of governance refers to the expenses which government incurs on administrative processes. According to Adewole and Osabuohien (2007), cost of governance is divided into two: recurrent administrative expenses and capital administrative expenses. They define cost of governance as costs associated with the running of government. Recurrent administrative expenses happen repeatedly on daily, weekly or even monthly basis. For instance, payment of pensions and salaries, maintenance of vehicles, payment of electricity and telephone bills, administrative overheads, water rates and insurance premium etc. Capital administrative expenses refer to the capital projects such as road construction, schools, hospitals, electrification projects etc. (Agu, 2013 cited in Adamu and Rasheed, 2016).

\subsection{Theoretical Framework}

This study is anchored on public interest theory propounded by lyoha, Gberevbie, Iruonagbe and Egharevba in the year, 2015 during their research work titled Cost of Governance: In Whose Interest? The theory is of the view that government is seen to be made up of individuals whose desire it is to serve the public by doing what is "right'. In this context, the government becomes an instrument that will or should improve the welfare of the society. The assumptions of this theory are that the society does not expect any 
unintended and unexpected consequences of government actions to arise in the course of the discharge of responsibilities. Hence, individuals in government being rational should be able to provide answers to a number of questions such as: what is the right cost of governance? Does current output correlate with level of spending, could more be achieved to improved capital projects. Recurrent expenditure is minimized with current spending, and could the same output be achieved with less spending? The theory is applicable to this study considering the fact that government is expected to provide for the welfare of members of the general public in all ramifications.

\subsection{Empirical Review}

Alwardat Benamraoui and Rieple (2015) examined the ability of value for money (VFM) audit procedures to improve performance in UK Public Sector Organizations. The objective of the study was to evaluate VFM audit as a potential important tool with which to improve institutional performance in the public sector. Semi-structured interviews for both auditors and auditees were chosen as data collection method. The interviews were recorded, transcribed and finally analyzed using descriptive statistics with the aid of special package for social sciences (SPSS, Version 20). The results showed that VFM audit was perceived as an important potential means with which to improve institutional performance in the public sector, but had been poorly implemented in the audited bodies. Moreover, the results of the study showed that difference in expectations and perceptions of role between the external VFM auditors and the auditees give rise to significant conflict. The recommendation was that clients expect the VFM auditors to identify areas where their performances need to be improved, suggest solution and then helps to implement the suggested solutions.

Mchopa (2015) studied the integrating management practices into the achievement of value for money in Tanzania public procurement. The study aimed at assessing the contribution of contracts management practices towards values for money achievement. Structured questionnaires and interviews were used for data collection while descriptive statistics was applied as a tool for data analysis. The results revealed that contract contained all the necessary conditions such as contract practices of time management, quality management and costs control were effective and resulted into value for money achievement. It was recommended that more efforts are needed to enhance supervision and enforce defect liability clause.

Agbo and Aruomoaghe (2014) examined performance audit as a tool for fighting corruption in the Nigerian public sector administration. A study of government ministries and local government councils in Edo and Delta States. The objectives of the study were to determine if the resources are being managed with due regard to economy, efficiency and effectiveness and whether accountability requirements are being met reasonably. The data for the study were collected with the aid of questionnaire while Pearson's correlation co-efficient was used for data analysis. The findings showed that performance audit could be an effective tool in curbing corruption. The recommendation was that performance audit report should be made public and stringent punishment should be melted on offenders to serve as deterrent to others.

Mahbuba (2012) examined the impact of performance (VFM) audit on government social pregramme: The Study was on forest management in Bangladesh with particular focus on social forestry. The objective was to analyze how management system procedures and practices ensure intended results. Chi-square was use for the analysis of the data that were gathered through both qualitative and quantitative means. The findings showed that most of the variables of economic use of resources showed positive correlation with the improved management of government programme, resulting in enhanced livelihood opportunities, increased participation, increased income and empowerment of beneficiaries.

Olurankinse (2012) empirically examined measures and strategies aimed at checking wasteful expenditure and keeping budget in line with global practice. Data were collected using structured questionnaires administered to 500 budget officers and accounting officers in various units of government in Ondo State, Nigeria. Analysis of data was done using descriptive statistics with the aid of SPSS version 20.0. The result of the analysis revealed that people who are concerned with budget formulation are not fully carried along and this accounted for the inadequacy of budget formulation. Besides, there is lack and disrespect for due process because of low level of compliance with budget provisions. In terms of 
monitoring and implementation, result showed that budgets are not well monitored and not fully implemented and this is evident in so many uncompleted and abandoned projects.

In another study Tanko et al. (2010) examine value for money audit in Nigeria local government councils. The objective of the study was to evaluate whether taxpayers funds are being utilized economically efficiently and effectively. The data for the study were collected with instrumentality of questionnaire while Chi-square was used for analysis data. The findings indicate that the managements of the local government areas do not follow due process in contract award and this has negative impact on the concept of value for money audit. The recommendation was that due process must be followed strictly in both contract award and implementation.

\section{Research Hypotheses}

The researcher developed the following null hypotheses using the three (3) elements of vfm audit from the literature reviewed.

$\mathrm{Ho}_{1}$ : Economy principle in procurement does not significantly affect cost of governance in local government councils in Nigeria.

$\mathrm{Ho}_{2}$ : Efficiency principle in utilization of resources does not significantly affect cost of governance in local government councils in Nigeria.

$\mathrm{Ho}_{2}$ : Effectiveness principle in budget implementation does not significantly affect cost of governance in local government councils in Nigeria.

\section{Methodology of Research}

This study employed cross-sectional survey design. This type of research design enables data to be collected from a population at a specific point in time. The appropriateness of this design is predicated on its ability to be used for measuring perceptions, attitudes, knowledge and orientation of people in a given population (Rubin and Babbie, 2005). The study was carried out in the thirteen (13) local government councils in Ebonyi State of Nigeria. The target population of this study is 286 staff of accounts and internal audit departments; with a sample size of 167 obtained using Taro Yamane's formular.

The respondents of this study are senior staff from grade level 7 and above in accounts and internal audit departments in the 13 councils headquarters. A total number of 167 well-structured questionnaires were administered to the targeted respondents, but only 108 were well filled and returned. The research instrument contains 16 metric questions on value for money audit decomposed as (economy, efficiency and effectiveness) and cost of governance against which the respondents were asked to indicate their level of agreement upon a point like scale (where $5=$ strongly agree; $4=a g r e e ; 3=$ Neutral or undecided; $2=$ disagree and $1=$ strongly disagree).

Table 1. Regression Results

\begin{tabular}{lcccc}
\hline \multicolumn{1}{c}{ Variables } & Std. Error & Beta Coefficients & t. stat. & Prob. \\
\hline Constant & 0.1147 & - & -2.715 & 0.000 \\
Sum_economy Princinpro & 0.046 & 0.382 & 1.652 & $0.0142^{*}$ \\
Sum_efficiency princinResUti & 0.44 & 0.438 & 4.307 & 0.5689 \\
Sum_effectivenessPrincinbdimp & 0.012 & 0.131 & -1.104 & $0.0052^{* *}$ \\
T-stat. & 2.146 & & & \\
\hline
\end{tabular}

Source: SPSS 2019 version 20.0

R-squared $=0.814$

R-squared adjusted $=0.763$

Durbin Watson $=1.784$

\section{Test of Hypotheses and Discussion of Findings}

For the purpose of achieving the objectives of the study, the research hypotheses were originally formulated in line with the specific objectives of the study. Statistical tools such as mean, standard deviation and multiple regression method with the aid of statistical package for social sciences (SPSS) version $\mathbf{2 0 . 0}$ were employed for testing the hypotheses of this study. The multiple regression method was 
anchored an ordinary least square (OLS). The decision rule for testing the hypotheses was anchored on the conventional probability values ( $P$-value) associated with regression outcome of the research base line model. The decision is stated thus: reject the null hypothesis if the probability value associated with the $t$ statistics of the coefficient is not significant at $10 \%, 5 \%$ or $1 \%$ and accept the alternately hypothesis and vice-visa. Technically expressed as:

If prob-value $=10 \%, 5 \%$ or $1 \%>$ reject $\mathrm{H}_{\circ}$ and accept $\mathrm{H}_{\mathrm{i}}$

But if prob-value $=10 \%, 5 \%$ or $1 \%>$ accept $\mathrm{H}_{\mathrm{o}}$ and reject $\mathrm{H}_{\mathrm{i}}$

Hypothesis 1: Economy principle in procurement does not significantly affect cost of governance in local government councils in Nigeria.

Table 1 showed that the $P$-value in respect to hypothesis 1 is 0.0142 , which is equal to $1.42 \%$. In line with the decision rule stated earlier, the P-value fall within the acceptable significant level of $1 \%$. Guided by the decision rule, the researcher accepted the alternate hypothesis and rejected the null hypothesis. The implication of this decision is that economy principle in procurement of works has significant effect on the overall cost of governance in Nigeria. This result is not in conformity with the researcher's a priori expectations because, the researcher's discussion interviews with the local government staff point to the fact that administrators of the councils do not adhere to the principle of economy in procurement.

However, the result of hypothesis 1(one) is in congruence with Mahbuba (2012) who evaluated the impact of performance audit on government social programmes. The finding showed that most of the variables of economic use of resources showed positive correlation with the improved management of government prorgramme, resulting in enhanced livelihood opportunities, increased participation, increased income and empowerment of beneficiaries.

Hypothesis 2: Efficiency principle in utilization of resources does not significantly affect cost of governance in local government councils in Nigeria.

Table 1 also showed that the $p$-value in respect to hypothesis 2 is 0.05689 which is equal to $=58.9 \%$. In line with decision rule guiding the study, the $p$-value did not fall within the acceptance significant range of $10 \%, 5 \%$ or $1 \%$. The implication of this decision is that the researcher accepted the null hypothesis and rejected the alternate hypothesis. This simply means that efficiency principle in utilization of resources has no significant effect on the cost of governance in Nigeria. This result agreed with Tanko et al. (2010) who examine value for money audit in Nigeria local government councils. The objective was to evaluate whether taxpayers funds were being utilized economically, efficiently and effectively. The findings indicated that the management of the local government areas in Nigeria does not follow due process in contract award and this has negative impact on the concept of value for money audit. Secondly, the research findings conformed to Alwardat et al. (2015) who examined the ability of value for money audit procedures to improve performance in UK public sector organizations. The result showed that value for money audit was perceived as an important potential means with which to improve institutional performance in the public sector, but had been poorly implemented in the audited bodies.

Hypothesis 3: Effectiveness principle in budget implementation does not significantly affect cost of governance in Nigeria.

The result presented in table 1 showed that the p-value in respect to hypothesis 3 is 0.0052 which is $0.5 \%$. Guided by the decision rule earlier stated, the $p$-value fall within the acceptable significant range. Therefore, $\mathrm{H}_{\mathrm{o}}$ was rejected while $\mathrm{Hi}$ was accepted. This implied that effectiveness principle in budget implementation has significant effect on cost of governance in Nigeria. However, this result did not agreed with Olurankinse (2012) who examined due process and budget implementation in the Nigerian public sector. The findings showed that people who are concerned with budget formulation are not fully carried along and this accounted for the inadequacy of budget formulation. Secondly, the result revealed that there is lack and disrespect for due process because of low level of compliance with budget provisions. In terms of monitoring and implementation, result showed that budget are not well monitored and not fully implemented and this is evident in so many uncompleted and abandoned projected.

Similarly the research result is out of the researcher's a priori expectation since most local government in Ebonyi seen not to have any stare to budget implementation arising from the way most political office holders fragrantly and recklessly handle budgets in the state. This is often worsening by the undue interference of state government in their financial dealings and appropriation. The general evidence of this undue interference is the renewed agitations and clamor for local government autonomy in Nigeria. 


\section{Reliability and Internal Consistency Analysis}

According to Hong and Cho (2011), research instrument is said to be reliable if such instrument proves beyond doubt, a considerable consistency in repeated applications.

In the present day research, reliability of research instrument is most often determined by the application Chronbach's alpha test or composite reliability which is usually less conservative in approach. In this study, the conventional conservative Chronbach alpha is applied in testing the reliability of the research instruments. Basically, the minimum threshold that must be achieved to the purpose of established reliability and consistency is $50 \%$ of Chronbach alpha value. From our research instrument, a total of four major constants (cost of governance, economy principle in procurement, efficiency principle in resource utilization and effectiveness principle in budget implementation) and 16 reflective indicators were analysized. From the basic analysis, the results indicate that all the variables showed high level of reliability and consistency. For instance, the overall reliability values of the major constructs of the study ranges from $87 \%, 90 \%, 98 \%$ and $68 \%$. With these results, it is evident that the research instrument is reasonably reliable even on a repeated application. The internal consistency is also further analyzed using the 16 reflective indicators. The output arising there from is also quite impressive.

The Chronbach alpha value 'if item is deleted' for the 16 reflective indicators ranges from $97 \%$ at the higher extreme and $55 \%$ at the lower extreme. Therefore, since they are within the acceptable benchmark, none of the research reflective indicators were deflected by researchers. See the table 2 for the bird-eye view of the reliability outcome.

Table 2. Reliability and Internal Consistency

\begin{tabular}{|c|c|c|c|c|c|}
\hline Construct/Variable & $\begin{array}{l}\text { No of } \\
\text { item }\end{array}$ & Variable & $\begin{array}{l}\text { Cronbach's } \\
\text { alpha }\left({ }^{\alpha c}\right)\end{array}$ & $\begin{array}{l}\text { SV if item } \\
\text { delected }\end{array}$ & $\begin{array}{c}\text { Cronbach it item } \\
\text { delected }\end{array}$ \\
\hline \multirow[t]{4}{*}{ Cost of governance } & 4 & Costgov1 & 0.878 & 5.957 & 0.785 \\
\hline & & Costgov2 & & 6.550 & 0.883 \\
\hline & & Costgov3 & & 5.214 & 0.667 \\
\hline & & Costgov4 & & 7.505 & 0.892 \\
\hline \multirow{4}{*}{$\begin{array}{l}\text { Economy principle in } \\
\text { procurement }\end{array}$} & 4 & Ecoprpro1 & 0.906 & 6.354 & 0.796 \\
\hline & & Ecoprpro2 & & 5.118 & 0.971 \\
\hline & & Ecoprpro3 & & 5.662 & 0.960 \\
\hline & & Ecoprpro4 & & 4.817 & 0.960 \\
\hline \multirow{4}{*}{$\begin{array}{l}\text { Efficiency Principle in } \\
\text { Resource Utilization }\end{array}$} & 4 & EffprRu1 & 0.984 & 4.883 & 0.837 \\
\hline & & EffprRu2 & & 5.311 & 0.558 \\
\hline & & EffprRu3 & & 5.210 & 0.873 \\
\hline & & EffprRu4 & & 5.603 & 0.629 \\
\hline \multirow{4}{*}{$\begin{array}{c}\text { Efficiency Principle in } \\
\text { budget } \\
\text { implementation }\end{array}$} & 4 & EffprBIm1 & 0.688 & 5.674 & 0.947 \\
\hline & & EffprBIm2 & & 5.306 & 0.963 \\
\hline & & EffprBIm3 & & 5.846 & 0.967 \\
\hline & & EffprBIm4 & & 5.163 & 0.751 \\
\hline
\end{tabular}

Source: SPSS 2019 Version 20.0

\section{Conclusions and Recommendations}

Corrupt practices and lack of adequate accountability in the management of public funds led to the introduction of value for money auditing. The result of this study revealed that adherence to economy principle in procurement practices and adherence to effectiveness principle in budget implementation among local government councils in Nigeria significantly affect cost of governance in Nigeria. However, the result also showed that local government administrators in Nigeria do not adhere to efficiency principle in utilization of resources. Thus, it has no effect on cost of governance in local government councils in Nigeria.

The implication of the findings is that the economy principle in procurement and effectiveness principle in budget implementation which have been achieved by the Local Government Administrators in Nigeria cannot singlehanded guarantee adequate welfare of the citizens until efficiency principle in utilization of resources is also achieved. It is at this point that the relevance of the theory of public interest which the study was anchored upon will be achieved. The findings of this study will be highly valuable to 
local government administrators as a policy instrument because it will engender strict adherence to the principles of value for money audit, (i.e. economy principle in procurement, efficiency principle in utilization of resources and effectiveness principle in budget implementation) for reduction of cost of governance in the Nigeria's local government councils.

Consequently, the researcher made the following recommendations:

1. A department should be created in office of the Auditor-general for local government to foresee and generate VFM audit annual reports. Anyone who indulges in embezzlement or diversion of public funds should be made to bear the full weight of the law irrespective of his/her position in the political sphere.

2. Expected performance or output of the local government councils in respect to each programme, should be well specified in each year's budget for easy implementation, proper monitoring and evaluation.

3. Ensuring transparency and competitiveness in the award of government contract, mainly through open competitive bidding process. This will ensure that the best and most qualified contractors, service providers and suppliers are engaged in the procurement process.

\section{References}

1. Achebe, C. (1984). The Trouble with Nigeria. Enugu: Fourth Dimension Publishers.

2. Adamu, A. and Rasheed, Z.H. (2016). High Cost of Government and the Challenges of National Development in Nigeria's Fourth Republic. Journal of Good Governance and Sustainable Development in Africa (JGGSDS), 3(1): 43-57.

3. Adewole, A.N. and Osabuohien, E.S.C. (2007). Analysis of the Cost of Governance and Options for its Reduction in Nigeria. Nigerian Journal of Economic and Social Studies, 49(1): 137-159.

4. Barnett, C., Barr, J., Christie, A., Duff, B. and Hext, S. (2010). Measuring the Impact and Value for Money of Governance and Conflict Programmes. Final Report Submitted by ITAB, P.34.

5. Ene, E. (2000). Value for Money Auditing in Public Sector. ICAN Student Newsletter, December.

6. Fluvian,G. (2006). The rising Cost of Governance in Africa. Journal of Public Administration, 22(9): 441-463.

7. Johson, I.E. (1996). Public Sector Accounting \& Financial Control. Lagos: Financial Training Nigeria.

8. Kandasamy, V. (2003). Value for Money Audit Process. National Education Conference, Canada p1.

9. Kalubanga, M. and Kakwezi, P. (2013). Value for Money Auditing and Audit Evidence from a Procurement Perspective - A Conceptual Paper. International Journal of Advances in Financial Management and Economics, 2(5): 115-124.

10. Nwosu, M.E. and Mshelia, M.I. (2015). Value for Money Audit. A veritable Tool for Expenditure Management. Internal Journal of Financial Research, 6:123-138.

11. Office of the Auditor General, Canada (OAG, Canada, 2010). Annual Report.

12. Okeke, M.I. and Eme, O.I. (2015). Cost of Governance and its Implication on Nigeria's Economy. Kuwait Chapter of Arabian Journal of Business and Management Review, 4(5): 44-61.

13. Okey, O.O. and Eduno, E.B. (2014). Corruption, Governance and Public Spending in Nigeria: Implication for Economic Growth. British Journal of Economics, Management and Trade, 4(11): 1679-1699.

14. Okwoli, A.A. (2004). Value for Money Auditing in the Nigeria Public Sector: its Problems and Prospects in the Next Millennium. Jos: Go-go Int'I Ltd.

15. Raymond, C.P. (1995). The Effect of Value for Money Audit in the Evaluation of Government Programmes. An M.Sc. Dissertation Submitted to Hong Kong Polytechnic University.

16. Rubin, A. and Babbie, E.R. (2005). Research Methods for Social Work. Belmont: Thomson Learning.

17. Tanko, M., Samuel, G. and Dabo, Z. (2010). Value for Money Audit in Nigerian Local Area Councils: An Empirical Examination. Proceedings of the North East Business and Economics, 113p. 